\title{
In an Attempt at Saving the Environment, Are You Instead Harming Yourself?
}

\author{
Ravneet Athwal ${ }^{1}$, Helen Heacock ${ }^{2}$ \\ 1 Lead Author, B. Tech Student, School of Health Sciences, British Columbia Institute of Technology, 3700 \\ Willingdon Ave, Burnaby, BC, V5G 3H2 \\ 2 Supervisor, School of Health Sciences, British Columbia Institute of Technology, 3700 Willingdon Ave, Burnaby, \\ $\mathrm{BC}, \mathrm{V} 5 \mathrm{G} 3 \mathrm{H} 2$
}

\begin{abstract}
Background

With the increasing shift to reusable shopping bags and the potential ban on plastic bags in Canada in the near future, the question arises as to whether consumers are aware of the proper practices to maintain a safe environment within the bags themselves. The reason for this study was to determine if people are aware of the need to keep specific bags for certain food groups and if they are aware of the need to wash and/or sanitize their reusable shopping bags due to the risk of cross-contamination. Usage of the same bag for various foods (e.g. lettuce and raw meat) without proper sanitation practices can lead to cross-contamination between the foods, and in turn, create a risk of food borne illness.
\end{abstract}

\section{Methods}

A survey created on Microsoft Office 365 Word was administered through Survey Monkey and distributed on Reddit, various social media, and by email. The survey collection ran for one week in the month of January 2020. The survey consisted of 14 questions and took approximately two to three minutes to complete.

\section{Results}

225 respondents filled out the online survey. The majority of survey responses were from British Columbia (47\%), were female (54\%), attended post-secondary institutions $(65 \%)$ and were between the ages of 20 to $30(46 \%)$. Nearly half of reusable shopping bag users use the same bag to store their fruits/vegetables and their meats, $61 \%$ of users have never cleaned their shopping bags, $7 \%$ clean them weekly, and only $1 \%$ clean their bag after every use. Those who mix produce and meats in the same bag are less likely to wash their RSBs $(p=0.0006)$. Males are less likely to wash their shopping bags than females $(\mathrm{P}=0.009) .97 \%$ of survey respondents were not provided with any cleaning instructions upon their purchase of a reusable shopping bag and $93 \%$ have never seen educational material presented on RSB cleaning and/or the risk of cross-contamination. $84 \%$ believe there is not appropriate awareness and knowledge among the general public on the cleaning requirements of reusable shopping bags and the potential risk of 
cross-contamination while $10 \%$ believe there is sufficient awareness. Not surprisingly, those who were not aware that shopping bags need to be cleaned between uses were less likely to wash them $\left(\mathrm{p}=7.804 \times 10^{-19}\right)$.

\section{Conclusion}

In conclusion: 1. people who are not aware that their RSBs need to be cleaned between uses are also less likely to clean them, 2. males are less likely to clean their reusable shopping bags, 3 . bags that contain both fruits/vegetables and meats in the same bags are also less likely to be cleaned, and 4 . bags that are used more frequently also cleaned more frequently. Further education on reusable shopping bags is needed along with the transition from plastic bags to reusable shopping bags. At the time of publication, the 2020 Covid-19 pandemic was rapidly spreading throughout the world. In order to prevent fomite spread of disease, British Columbia forbade the use of RSBs in grocery stores, resulting in a proliferation of plastic bags. Time will tell when, and if, RSBs will be permitted for grocery shopping.

\section{Keywords}

RSB, reusable shopping bags, shopping bags, plastic bags, cross-contamination, FBI, foodborne illness 


\section{Introduction}

Over the past few decades, there has been an increasing concern for the environment and an increasing shift of consumers switching over from plastic shopping bags to reusable shopping bags (RSB). As mentioned by Prime Minister Justin Trudeau in a news release from June 2019 (17), the Government of Canada will "ban harmful single-use plastics as early as 2021 (such as plastic bags...).”

Plastic has been widely used since the late 1900's and is still commonly used today because it is easily available and cost efficient. However, with the growing concern to protect the environment and oceans from plastic pollution, the general public is changing their ways and switching over to other materials, such as the increased use of reusable shopping bags instead of plastic bags.

With the increased shift to reusable shopping bags and the potential ban on plastic bags in Canada in the near future, the question then arises as to whether consumers are aware of the proper practices to maintain a safe environment within the bags themselves. The reason for this study was to determine if people are aware of the need to keep specific bags for certain food groups and if they are aware of the need to wash and/or sanitize their reusable shopping bags due to the risk of cross-contamination. Usage of the same bag for various foods (ex. lettuce and raw meat) without proper sanitation practices can lead to crosscontamination between the foods, and in turn, create a risk of food borne illness.

\section{Literature Review}

\section{Reusable Shopping Bag Material}

There are various materials used for reusable shopping bags available on the market. They can be manufactured from cotton, hemp, polyester, nonwoven polypropylene, recycled PET (polyethylene terephthalate), jute, nylon, and poly-nylon. Cotton, polyester, hemp reusable bags are the easiest to wash as they are machine washable in cold water and can then be air dried. However, nonwoven propylene, jute, recycled PET, nylon, and poly-nylon reusable bags are more difficult to wash as they need to be hand washed using warm water and antibacterial soap and then air dried (11).

\section{Cross-contamination}

The Canadian Food Inspection Agency (5) defines cross-contamination as "... the unintentional physical movement or transfer of a biological, chemical or physical hazard from a person, object, or place to another... often a contributing factor in outbreaks of foodborne illness." Crosscontamination resulting from placing meats and vegetables or ready-to-eat foods to raw foods in the same bag can lead to foodborne illnesses. Another potential source of crosscontamination in reusable shopping bags can be the multi-use of the bags. The public not only uses them to store their groceries, but also for other personal uses, such as for transporting yoga and gym gear and for carrying library books. According to Gordon Food Service (12), 4 million foodborne illnesses occur in Canada annually. Most of these illnesses are preventable if food was handled properly, including correctly using reusable shopping bags. 
San Francisco County was the first United States jurisdiction to implement a ban on plastic bags in 2007. A study (8) looked at data from San Francisco emergency rooms between 2005 to 2010 to determine if there was a relationship between the plastic bag ban and changes in foodborne illness cases. The study discovered that the ban lead to an immediate increase in infections when it was implemented. There were significant increased hospitalizations from Escherichia coli, salmonella, and campylobacter infections. It was concluded that the ban was associated with a $46 \%$ increase in deaths from foodborne illnesses.

\section{Bacteria presence in reusable shopping bags}

Studies show that consumers only wash their RSBs if they are visibly stained or dirty (13). However, a bag's appearance does not determine how dirty or contaminated the bag may actually be. A study conducted in Portugal in 2018 (2) demonstrated that appearance is not a reliable method in determining the contaminants found in a bag.

Researchers have performed tests and identified reusable shopping bags containing mold, yeast, and microorganisms such as Escherichia coli, staphylococcus, salmonella, norovirus and campylobacter (19). Coliform bacteria have been detected in $51 \%$ of bags tested in a study (19), while another study identified $12 \%$ of the bags containing unacceptable coliform counts (9). The presence coliforms indicate that raw meats or uncooked food products have contaminated the reusable shopping bag. The presence of yeast and mold may not be a cause for concern among the general public, but it can greatly affect the health of immunocompromised individuals and those that have allergies.

In 2010, there was a norovirus incident where 6 members of an Oregon soccer team became ill with acute gastroenteritis. Public Health investigators determined that the norovirus was transmitted by a reusable shopping bag (9). Previously, reusable shopping bags had not generally been associated with illness cases as shopping bags are not thought to be a common mode of transmission of disease.

Transmission pathway of contamination via reusable shopping bags

Researchers (14) created a surrogate bacteriophage, termed MS2, that was similar in structure, size, model of survival, morphology, and transport characteristics to mimic norovirus, in order to test the transmission pathway of a norovirus in a conventional grocery store setting. Reusable shopping bags were sprayed with this surrogate and provided to volunteer shoppers as they entered the grocery store, then study personnel swabbed all surfaces touched by the volunteer shoppers to recover the MS2 surrogate. The highest concentration of the surrogate bacteriophage MS2 was found in the reusable shopping bags, the $2^{\text {nd }}$ highest concentration was discovered on the hands of the volunteer customers, and following closely behind in the $3^{\text {rd }}$ place, MS2 was identified on the hands of clerks and packaged foods. This shows that not only does the microorganism harm the food stored within the bag, but also surfaces and people the reusable bags come into contact with. This can be especially dangerous among vulnerable populations and even to those who do not personally use the reusable shopping bags themselves. 
In the grocery bag controversy report (13), the Silverhill's Grocery Shopping Bags 2011 Toronto Resident Survey findings was examined. The report concluded that not only are the users of reusable shopping bags at risk, but the pathogens are also capable of being transmitted to other individuals shopping in the same stores. Common shopping practices such as placing the bags in shopping carts or on the conveyor belts at checkout lead to possible sources of contamination, as seen in the study that followed the transmission pathway.

Separating meats from vegetables

Just as you would not cut your vegetables and meat on the same cutting board, you should not place them in the same bag. The juices of the meat are able to leak out and contaminate the other items that are present within the same bag. If the reusable shopping bag also contains fruits or vegetables, there would be introduction of bacteria into those food items and could result in cross-contamination. Most people do not realize that it is not just during food preparation that cross-contamination can occur, it is also during the storage and transportation of food items. A study (19) surveying consumers concluded that $50 \%$ of people use their bags more than once a day and $75 \%$ of them do not separate out the meats and vegetables.

\section{Reusable shopping bags hygiene}

Studies indicate that individuals do not frequently wash their reusable shopping bags. In fact, one study (19) showed that only 3\% people surveyed said they regularly clean their bags. In another study (13), 46\% indicated that they never wash or clean their reusable bags, while $44 \%$ said that they seldom do so. Reusable shopping bags that are kept in the trunk of a vehicle, in which meat juice has leaked, can exhibit bacterial growth within 2 hours of storage, a trunk temperature of $47^{\circ} \mathrm{C}$ leads to a bacterial count increase of 10-fold (19). The increase in temperature and food in the bags result in increase of bacterial counts. This may be potentially dangerous because it is common practice to have groceries lay in the trunk of the vehicle while people run errands, resulting in passing the 2-hour mark. A study (13) survey showed that $27 \%$ of individuals store their reusable shopping bags inside their cars.

The Government of Canada (6) suggests buying "cold or frozen food towards the end of your shopping trip" to reduce the amount of time the food is exposed to room temperature and that they should be stored in the refrigerator or freezer immediately. As described by BCCDC (3), the danger zone exists between $4^{\circ} \mathrm{C}$ and $60^{\circ} \mathrm{C}$ or $40^{\circ} \mathrm{F}$ and $140^{\circ} \mathrm{F}$. In this temperature range, bacteria have the ability to grow rapidly because this is this is their optimal growth condition. Food should not be kept within this temperature range for greater than 2 hours or if so, it should be discarded. As mentioned by the Government of Manitoba (7), if the room temperature is above $35^{\circ} \mathrm{C}\left(90^{\circ} \mathrm{F}\right)$, food should not be left out for longer than one hour.

A study (19) looked at both machine and hand washing methods of cleaning reusable shopping bags. With and without the presence of bleach, both washing methods resulted in decreasing coliform and other bacteria counts within the bag to below detectable limits. 
Gaps in knowledge

There is awareness of the need of switching to reusable shopping bags in order to protect the environment and our oceans. However, not much thought is given to promoting the sanitation and hygiene of these bags. In the few studies that surveyed individuals, people do not clean their bags, separate meats from ready to eat foods, or store their reusable shopping bags in safe environments. Most of the studies conducted perform microbiological tests to determine the bacterial presence on the bags or their potential transmission methods. But more surveys are required to determine what people are aware of, not necessarily their actions because knowledge does not always translate into action. There is need to determine what information people have been exposed to, and what are they aware of when using or maintaining their reusable shopping bags. Without this necessary information, there is no starting point on educational campaigns or knowledge of what specific population groups may need to be targeted more than others.

\section{Purpose of the Study}

The purpose of this study was to determine if people are aware of the safe practices when it comes to the use of reusable shopping bags and whether they are applying those practices. This study was conducted through a survey questionnaire. A similar study was conducted by Ester Tong in 2010 (16) and this study conducted in 2020, was a 10-year follow-up to determine if consumers are now more aware of the hygiene practices around RSBs and if they have received further information on RSBs.

\section{Materials and Methods}

A number of materials were used in this research study. The survey was produced using Microsoft Office 365 Word (10) on a personal password-protected laptop. The survey consisted of questions adapted from past studies described in the literature review. The survey was conducted on Survey Monkey (15) and distributed using Reddit personal account, Facebook personal account, Instagram personal account, BCIT email and Hotmail email account distribution.

The survey was open for the time period of a week in the month of January 2020. It consisted of 14 questions and it took approximately two - three minutes to complete.

\section{Results}

A total of 225 eligible respondents filled out the online survey $(n=225)$. No eligible participant data responses from the online survey responses were eliminated for the study. All descriptive data was exported from SurveyMonkey (15) and the calculated statistics are presented below.

Table 1. Gender

\begin{tabular}{|l|r|l|}
\hline What is your gender? & Response & $\mathbf{\%}$ \\
\hline Female & 123 & $54.67 \%$ \\
\hline Male & 94 & $41.78 \%$ \\
\hline Other & 2 & $0.89 \%$ \\
\hline Prefer not to say & 6 & $2.67 \%$ \\
\hline Total & 225 & \\
\hline
\end{tabular}


Table 2. Education Level

\begin{tabular}{|l|r|r|}
\hline $\begin{array}{l}\text { What is your highest } \\
\text { education level? }\end{array}$ & Response & \multicolumn{1}{l|}{$\%$} \\
\hline Less than high school & 4 & $1.78 \%$ \\
\hline High school & 37 & $16.44 \%$ \\
\hline Post-secondary & 147 & $65.33 \%$ \\
\hline Graduate school & 32 & $14.22 \%$ \\
\hline Other & 0 & $0.00 \%$ \\
\hline Prefer not to say & 5 & $2.22 \%$ \\
\hline Total & 225 & \\
\hline
\end{tabular}

Table 3. Residence

\begin{tabular}{|l|r|r|}
\hline $\begin{array}{l}\text { Where do you currently } \\
\text { reside? }\end{array}$ & Response & \multicolumn{1}{l|}{$\%$} \\
\hline British Columbia & 107 & $47.56 \%$ \\
\hline Alberta & 1 & $0.44 \%$ \\
\hline Manitoba & 49 & $21.78 \%$ \\
\hline New Brunswick & 42 & $18.67 \%$ \\
\hline Nova Scotia & 11 & $4.89 \%$ \\
\hline Ontario & 10 & $4.44 \%$ \\
\hline Northwest Territories & 2 & $0.89 \%$ \\
\hline Yukon & 2 & $0.89 \%$ \\
\hline Quebec & 1 & $0.44 \%$ \\
\hline Prefer not to say & 0 & $0.00 \%$ \\
\hline Total & 225 \\
\hline
\end{tabular}

Table 4. Age

\begin{tabular}{|l|r|r|}
\hline How old are you in years? & Response & \multicolumn{1}{l|}{$\%$} \\
\hline$<20$ & 22 & $9.78 \%$ \\
\hline $20-30$ & 104 & $46.22 \%$ \\
\hline $31-40$ & 50 & $22.22 \%$ \\
\hline $41-50$ & 24 & $10.67 \%$ \\
\hline $51-60$ & 16 & $7.11 \%$ \\
\hline$>60$ & 5 & $2.22 \%$ \\
\hline Prefer not to say & 3 & $1.33 \%$ \\
\hline Skipped & 1 & $0.44 \%$ \\
\hline Total & 225 & \\
\hline
\end{tabular}

The majority of survey responses were from British Columbia (47\%) (Table 3 ), were female (54\%) (Table 1), had postsecondary education (65\%) (Table 2$)$ and were between the ages of 20 to $30(46 \%)$ (Table 4).

Table 5. Fee impact on RSB switch

\begin{tabular}{|l|r|l|}
\hline $\begin{array}{l}\text { Did the plastic bag fee impact your } \\
\text { decision on switching to reusable } \\
\text { shopping bags? }\end{array}$ & Response & $\%$ \\
\hline Yes & 77 & $34.22 \%$ \\
\hline No & 138 & $61.33 \%$ \\
\hline Other & 9 & $4.00 \%$ \\
\hline Prefer not to say & 1 & $0.44 \%$ \\
\hline Total & 225 \\
\hline
\end{tabular}

The plastic bag fee that is in place in certain regions of Canada did not appear to impact the decision for $61 \%(n=138)$ of users to switch to reusable shopping bags. However, 34\% $(n=77)$ did feel the plastic bag fee impacted their decision (Table 5).

Table 6. Frequency of RSB wash

\begin{tabular}{|l|r|l|}
\hline $\begin{array}{l}\text { How often do you use reusable } \\
\text { shopping bags in a week? }\end{array}$ & Response & \multicolumn{1}{l|}{$\%$} \\
\hline Daily & 30 & $13.33 \%$ \\
\hline 3-5 times a week & 44 & $19.56 \%$ \\
\hline 1-2 times a week & 77 & $34.22 \%$ \\
\hline A few times a month & 39 & $17.33 \%$ \\
\hline A few times a year & 24 & $10.67 \%$ \\
\hline Other & 8 & $3.56 \%$ \\
\hline Prefer not to say & 3 & $1.33 \%$ \\
\hline Total & 225 & \\
\hline
\end{tabular}

In terms of the frequency of using their reusable shopping bags, 34\% $(n=77)$ use their bags $1-2$ times a week, $19 \%(\mathrm{n}=$ 44) use RSBs 3 - 5 times a week, 17\% $(\mathrm{n}=$ 39) use their RSBs a few times a month, $13 \%(\mathrm{n}=30)$ use their bags daily, and $10 \%$ $(\mathrm{n}=24)$ only use their bags a few times in a year (Table 6). 


\section{Do you use the same bag for both fruits/vegetables and meats?}

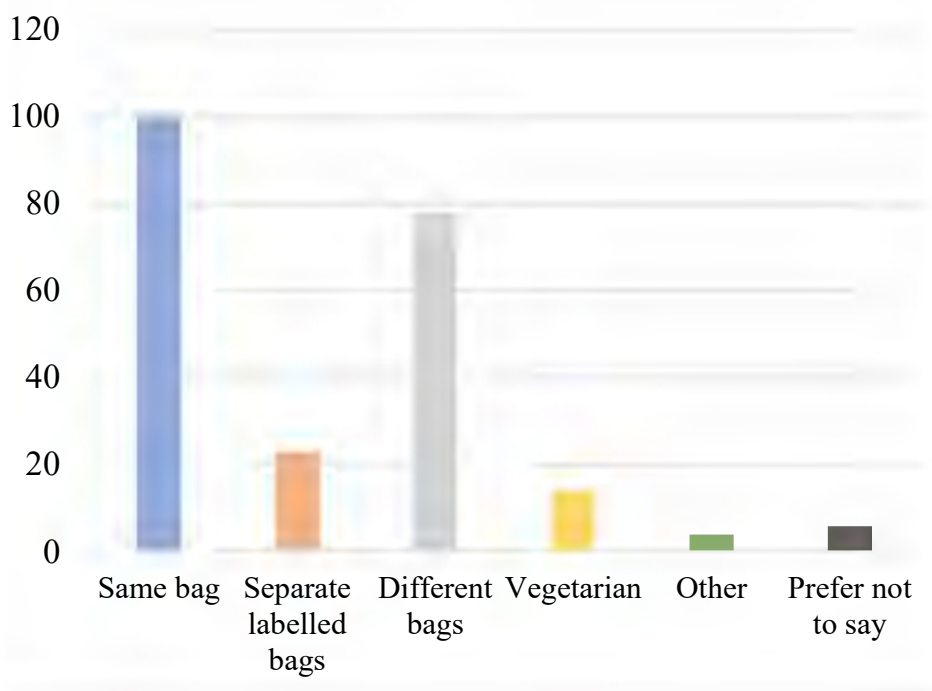

Figure 1. Food Use of RSB

$$
44 \%(n=100) \text { of reusable shopping }
$$

bag users use the same bag to store their fruits/vegetables and their meats, 34\% $(n=$ 78) do not store them in the same bag, and $10 \%(n=23)$ have separate labelled bags for them (Figure 1).

\section{Do your reusable shopping bags hold multiple uses?}

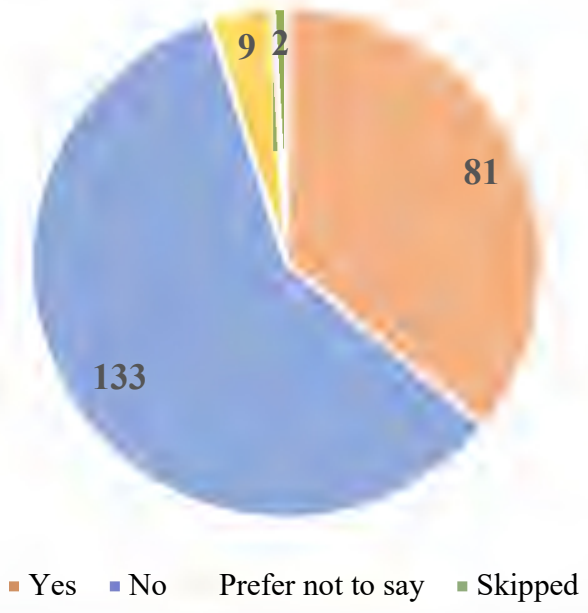

Figure 2. Multi-Use of RSB
In terms of the multi-use of RSBs, $59 \%(\mathrm{n}=133)$ of respondents do not use their RSBs for multiple uses, whereas 36\% $(\mathrm{n}=81)$ do use them for multiple uses. Most of the respondents that answered yes use their bags as sports bags, book bags, laundry bags, cat bags, diaper bags, camping bags, and general travel totes (Figure 2).

\section{Are you aware that reusable shopping bags} need to be cleaned between uses?

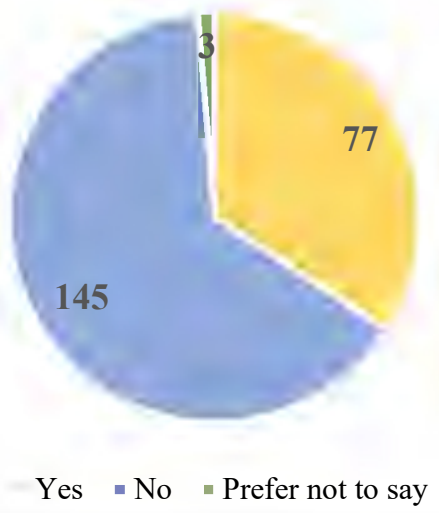

Figure 3. Awareness of RSB Cleaning

$64 \%(n=145)$ of the RSB users are not aware that the reusable shopping bags need to be cleaned between uses, while $36 \%$ $(\mathrm{n}=81)$ are aware of this. (Figure 3$)$.

\section{How often do you clean your reusable shopping bags?}

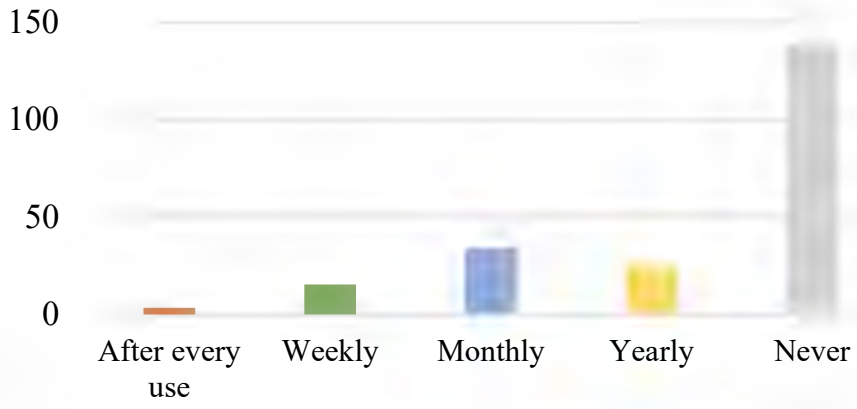

Figure 4. Frequency of RSB Cleaning 
$61 \%(n=138)$ of users have never cleaned their shopping bags, $11 \%(n=25)$ clean them yearly, $15 \%(n=34)$ clean them monthly, $7 \%(\mathrm{n}=16)$ clean them weekly, and only $1 \%(n=4)$ clean their bag after every use (Figure 4).

Table 7. Cleaning instructions

\begin{tabular}{|l|r|r|}
\hline $\begin{array}{l}\text { When purchasing your reusable } \\
\text { shopping bags, were you provided } \\
\text { with cleaning instructions? }\end{array}$ & Response & \multicolumn{1}{l|}{$\%$} \\
\hline Yes & 6 & $2.67 \%$ \\
\hline No & 218 & $96.89 \%$ \\
\hline Skipped & 1 & $0.44 \%$ \\
\hline Total & 225 & \\
\hline
\end{tabular}

\section{Have you seen educational materials presented on reusable shopping bag cleaning and/or risk of cross- contamination?}

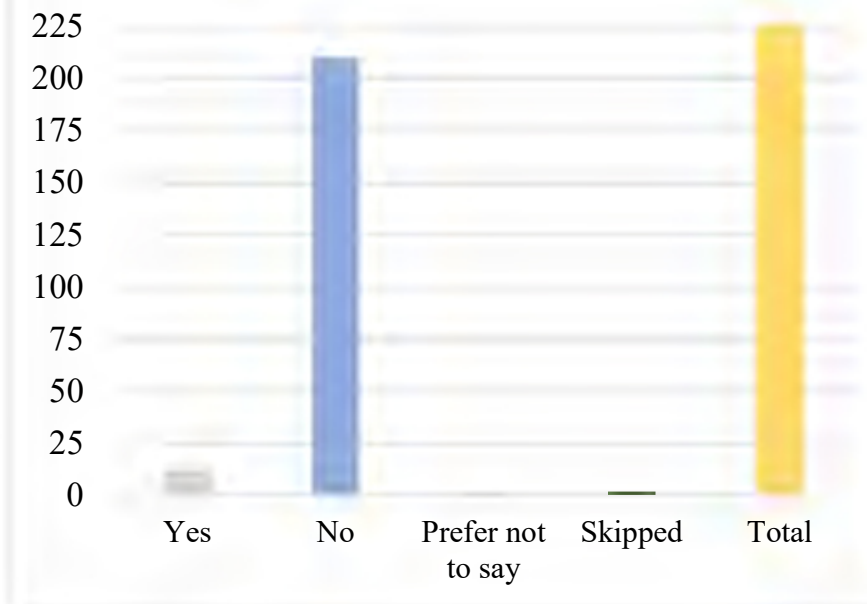

Figure 5. Education Material
Table 8. Public awareness and knowledge

\begin{tabular}{|l|r|r|}
\hline $\begin{array}{l}\text { Do you believe there is appropriate } \\
\text { awareness and knowledge among the } \\
\text { general public on the cleaning } \\
\text { requirements of reusable shopping bags } \\
\text { and the potential risk of cross- } \\
\text { contamination? }\end{array}$ & Response & $\%$ \\
\hline Yes & & \\
\hline No & 23 & $10.22 \%$ \\
\hline Other & 191 & $84.89 \%$ \\
\hline Prefer not to say & 9 & $4.00 \%$ \\
\hline Skipped & 1 & $0.44 \%$ \\
\hline Total & 1 & $0.44 \%$ \\
\hline
\end{tabular}

$97 \%$ of survey respondents were not provided with any cleaning instructions upon their purchase of a reusable shopping bag (Table 7) and 93\% have never seen educational material presented on reusable shopping bag cleaning and/or the risk of cross-contamination (Figure 5). 84\% believe there is not appropriate awareness and knowledge among the general public on the cleaning requirements of reusable shopping bags and the potential risk of crosscontamination while $10 \%$ believe there is appropriate awareness (Table 8).

\section{Results of Inferential Statistics}

Inferential statistical analysis of the nominal data was conducted with chi-square tests to assess potential associations between two categorical responses. A p-value of 0.05 was used to determine significant findings of the data. For data results where the answers "Prefer not to say" and "Other? Please specify" add up to $5 \%$ or less, they have been removed to provide accurate results and further eliminate alpha and beta errors. Inferential statistics tested was done using the chi-square test.

The following table (Table 9) summarizes the statistical tests that were conducted and their associated hypotheses. 
Significant differences were found in four of the ten null hypotheses tested. These four hypotheses compared: 1 . the frequency of RSB cleaning and how often the RSBs are used in a week, 2. how often RSBs are cleaned and whether the same bag is used for fruits/vegetables and meats, 3. whether gender affects how often RSBs are cleaned, and 4. if frequency of cleaning is associated with awareness that RSBs need to be cleaned between uses.

The overall results show that people do not clean their reusable shopping bags and more needs to be done to promote the importance and health concerns when it comes to washing these bags.

Table 9. Results of statistical testing

\begin{tabular}{|c|c|c|}
\hline$H_{0}$ and $H_{A}$ & Result & Conclusion \\
\hline $\begin{array}{l}\text { There is no association } \\
\text { between how often } \\
\text { RSBs are used in a } \\
\text { week and whether the } \\
\text { same bag is used for } \\
\text { both fruits/vegetables } \\
\text { and meats. } \\
\text { There is an association } \\
\text { between how often } \\
\text { RSBs are used in a } \\
\text { week and whether the } \\
\text { same bag is used for } \\
\text { both fruits/vegetables } \\
\text { and meats. }\end{array}$ & $\begin{array}{l}\text { P-value = } \\
0.468\end{array}$ & $\begin{array}{l}\text { Do not reject } \mathrm{H}_{0} \\
\text { and conclude there } \\
\text { is no association } \\
\text { between how often } \\
\text { RSBs are used in a } \\
\text { week and whether } \\
\text { the same bag is } \\
\text { used for both } \\
\text { fruits/vegetables } \\
\text { and meats. }\end{array}$ \\
\hline $\begin{array}{l}\text { There is no association } \\
\text { between how often } \\
\text { RSBs are used in a } \\
\text { week and how often } \\
\text { RSBs are cleaned. } \\
\text { There is an association } \\
\text { between how often } \\
\text { RSBs are used in a } \\
\text { week and how often } \\
\text { RSBs are cleaned. }\end{array}$ & $\begin{array}{l}\text { P-value = } \\
0.006\end{array}$ & $\begin{array}{l}\text { Reject } \mathrm{H}_{0} \text { and } \\
\text { conclude that there } \\
\text { is an association } \\
\text { between how often } \\
\text { RSBs are used in a } \\
\text { week and how often } \\
\text { RSBs are cleaned. } \\
\text { Bags that are used } \\
\text { more frequently } \\
\text { also cleaned more } \\
\text { frequently. }\end{array}$ \\
\hline $\begin{array}{l}\text { There is no association } \\
\text { between how often } \\
\text { RSBs are cleaned and } \\
\text { whether the same bag }\end{array}$ & $\begin{array}{l}\text { P-value = } \\
0.0006\end{array}$ & $\begin{array}{l}\text { Reject } \mathrm{H}_{0} \text { and } \\
\text { conclude that there } \\
\text { is an association } \\
\text { between how often }\end{array}$ \\
\hline
\end{tabular}

is used for fruits/vegetables and meats.

There is an association between how often RSBs are cleaned and whether the same bag is used for fruits/vegetables and meats.

RSBs are cleaned and whether the same bag is used for fruits/vegetables and meats.

Bags that contain both fruits/vegetables and meats in the same bags are also less likely to be cleaned.

There is no association between if RSBs hold multiple uses and if the same bag is used for fruits/vegetables and meats.

There is an association between if RSBs hold multiple uses and if the same bag is used for fruits/vegetables and meats.

There is no association between how often RSBs are used in a week and whether RSBs hold multiple uses.

$\mathrm{P}$-value $=$ 0.236

Do not reject $\mathrm{H}_{0}$ and conclude there is no association between if RSBs hold multiple uses and if the same bag is used for fruits/vegetables and meats.

There is an association

between how often

RSBs are used in a week and whether RSBs hold multiple uses.

There is no association between where people reside and if they have seen educational material presented on RSB cleaning and the risk of crosscontamination.

There is an association between where people reside and if they have seen educational material presented on RSB cleaning and the risk of crosscontamination.

\section{Do not reject $\mathrm{H}_{0}$ \\ $\begin{array}{ll}\text { P-value }= & \text { Do not reject } \mathrm{H}_{0} \\ 0.247 & \text { and conclude there }\end{array}$ is no association between how often RSBs are used in a week and whether RSBs hold multiple uses.

(2)

(n)




\begin{tabular}{|c|c|c|}
\hline $\begin{array}{l}\text { There is no association } \\
\text { between education } \\
\text { level and whether the } \\
\text { same bag is used for } \\
\text { both fruits/vegetables } \\
\text { and meats. } \\
\text { There is an association } \\
\text { between education } \\
\text { level and whether the } \\
\text { same bag is used for } \\
\text { both fruits/vegetables } \\
\text { and meats. }\end{array}$ & $\begin{array}{l}\text { P-value = } \\
0.569\end{array}$ & $\begin{array}{l}\text { Do not reject } \mathrm{H}_{0} \\
\text { and conclude there } \\
\text { is no association } \\
\text { between education } \\
\text { level and whether } \\
\text { the same bag is } \\
\text { used for both } \\
\text { fruits/vegetables } \\
\text { and meats. }\end{array}$ \\
\hline $\begin{array}{l}\text { There is no association } \\
\text { between gender and } \\
\text { how often RSBs are } \\
\text { cleaned. } \\
\text { There is an association } \\
\text { between gender and } \\
\text { how often RSBs are } \\
\text { cleaned. }\end{array}$ & $\begin{array}{l}\text { P-value }= \\
0.009\end{array}$ & $\begin{array}{l}\text { Reject } \mathrm{H}_{0} \text { and } \\
\text { conclude that there } \\
\text { is an association } \\
\text { between gender and } \\
\text { how often RSBs are } \\
\text { cleaned. } \\
\text { Males are less } \\
\text { likely to clean their } \\
\text { reusable shopping } \\
\text { bags. }\end{array}$ \\
\hline $\begin{array}{l}\text { There is no association } \\
\text { between where people } \\
\text { reside and if they are } \\
\text { aware that RSBs need } \\
\text { to cleaned between } \\
\text { uses. } \\
\text { There is an association } \\
\text { between where people } \\
\text { reside and if they are } \\
\text { aware that RSBs need } \\
\text { to cleaned between } \\
\text { uses. }\end{array}$ & $\begin{array}{l}\text { P-value = } \\
0.614\end{array}$ & $\begin{array}{l}\text { Do not reject } \mathrm{H}_{0} \\
\text { and conclude there } \\
\text { is no association } \\
\text { between where } \\
\text { people reside and if } \\
\text { they are aware that } \\
\text { RSBs need to } \\
\text { cleaned between } \\
\text { uses. }\end{array}$ \\
\hline $\begin{array}{l}\text { There is no association } \\
\text { between how often } \\
\text { RSBs are cleaned and } \\
\text { if people are aware that } \\
\text { RSBs need to be } \\
\text { cleaned between uses. } \\
\text { There is an association } \\
\text { between how often } \\
\text { RSBs are cleaned and } \\
\text { if people are aware that } \\
\text { RSBs need to be } \\
\text { cleaned between uses. }\end{array}$ & $\begin{array}{l}\text { P-value } \\
=7.804 \\
\times 10^{-19}\end{array}$ & $\begin{array}{l}\text { Reject } \mathrm{H}_{0} \text { and } \\
\text { conclude that there } \\
\text { is an association } \\
\text { between how often } \\
\text { RSBs are cleaned } \\
\text { and if people are } \\
\text { aware that RSBs } \\
\text { need to be cleaned } \\
\text { between uses. } \\
\text { People that are not } \\
\text { aware that their } \\
\text { RSBs need to be } \\
\text { cleaned between } \\
\text { uses are also less } \\
\text { likely to clean } \\
\text { them. }\end{array}$ \\
\hline
\end{tabular}

\section{Discussion}

The results indicate people are not aware of the safe practices regarding the use of reusable shopping bags and are thus not applying those practices. These results correspond to Ester Tong's study conducted in 2010 (4) where she concluded that the behaviour of consumers regarding RSBs must be improved.

The main conclusions that can be drawn from this study are that: 1 . Bags that contain both fruits/vegetables and meats in the same bags are also less likely to be cleaned ( $\mathrm{P}=0.0006), 2$. Males are less likely to clean their reusable shopping bags $(\mathrm{P}=0.009) 3$. Bags that are used more frequently are also cleaned more frequently $(\mathrm{P}=0.006)$., and 4. People who are not aware that their RSBs need to be cleaned between uses are also less likely to clean them $\left(\mathrm{P}=7.804 \times 10^{-19}\right)$.

The study results have provided evidence that $44.4 \%(n=100)$ of Canadians use the same bag for both fruits/vegetables and meats. This practice can lead to a great increase in the number of foodborne illnesses (6). Unlike plastic bags that are discarded after each use, the reusable shopping bags contain the "juices" from previous foods placed in the bag and can contaminate food if it is reused without proper cleaning procedures in between uses. $64.4 \%(n=145)$ of respondents were not aware that their reusable shopping bags need to be cleaned between uses and $61.3 \%(\mathrm{n}=$ 138) said they never clean their RSBs. Other studies have shown $46 \%$ of respondents (13) and $97 \%$ of users (19) have never cleaned their RSBs.

This research suggests that the plastic bag fee does not have a great impact on the consumer choice between a plastic shopping bag or a reusable shopping bag as 
the fee did not impact the decision of $61 \%$ $(n=138)$ of individuals to switch to RSBs. Other studies (13) have shown that only $18 \%$ of users claimed cost and $2 \%$ believed financial incentives were their reason when choosing the type of grocery bag to use.

The lack of public education and awareness around safe practices and handling of reusable shopping bags is evident in the response data. $96.9 \%(\mathrm{n}=$ 218) of Canadians were not provided with any cleaning instructions during the purchase of their reusable shopping bags, $93.3 \%(n=210)$ had not seen any educational material presented on cleaning practices or the risk of cross-contamination, and $84.9 \%(\mathrm{n}=191)$ do not believe there is appropriate awareness and knowledge among the general public. Further education on reusable shopping bags is needed along with the transition from plastic bags to reusable shopping bags. As every new product requires instructions and awareness, so too do reusable shopping bags in order to prevent illnesses that could be averted through use of public education.

The findings of this research study are considered valid because they confirm previous research findings and an adequate sample size was obtained.

Through this research study, it is evident that though there is public awareness and motivation to eliminate the use of plastic to protect the environment, the switch from plastic shopping bags to reusable shopping bags may be leading to added difficulties. Further public education is required to ensure public safety and reduce the risk of cross-contamination and foodborne illnesses that may occur.

\section{Limitations}

The study was limited in time as the survey ran for only one week in the month of January 2020. This limitation restricted the sample size and could be tackled by extending the survey response collection period. A pilot study was conducted using in-person surveys. By continuing that survey method and offering prize draws, it should have led to an increased sample size. However, in order to maintain consistency in the survey response method type, the pilot study responses were eliminated. An increase in the sample size would increase the internal and external validity of the study results. The survey responses collected did not include responses from every province and territory in Canada. In order for the survey results to truly reflect the Canadian population, survey responses should have been collected universally throughout the country.

\section{Knowledge Translation}

It is anticipated that the findings can be translated into policy changes for: 1 . the grocery store clerks and their personal sanitation methods while at work and, 2. ensuring surfaces such as conveyor belts and checkout counter surfaces are regularly sanitized. The findings can also be translated to further public education that is essential to raise awareness on this topic as the use of reusable shopping bags is on the rise. There could be promotion of an in-store hand hygiene campaign. The reusable shopping bags can come with tags that provide instructions on sanitation of the bags (i.e. type of sanitation, concentration, how frequently it is needed) and the need to separate raw and ready to eat foods. Education, promotional pamphlets, posters, or social media campaigns can be created by the Health Authorities or BCCDC to raise 
awareness in the public of the importance of sanitation of the reusable shopping bags. A module about RSB usage and cleaning can be added to the FoodSafe course to educate restaurant operators and staff.

\section{Future Studies}

The following future studies are recommended:

- Follow-up survey after the distribution of educational material to determine if it has led to changes in RSB cleaning practices

- Microbial testing of RSBs to determine where microbial growth is likely to occur

- Microbial testing of high-touch areas in grocery stores to determine where RSBs are likely to be contaminated

- Microbial testing of various RSB cleaning procedures to determine their efficiency

- Virus testing to determine the effectiveness of various RSB cleaning procedures

\section{Conclusions}

The study concludes that:

1. Bags that contain both fruits/vegetables and meats in the same bags are also less likely to be cleaned

2. Males are less likely to clean their reusable shopping bags

3. Bags that are used more frequently also cleaned more frequently

4. People that are not aware that their RSBs need to be cleaned between uses are also less likely to clean them
With the increased focus on reusable shopping bags, plastic reduction, and the plastic bag ban coming into effect in many regions across Canada, public education of the safe practices to the use of reusable shopping bags is essential to prevent a spike in foodborne illnesses due to crosscontamination and lack of bag hygiene. This is a situation that is easily preventable through adequate education and public awareness. The author believes that the results are valid and can be extrapolated all over the developed world, specifically Canada, because a lack of bag cleaning and hygiene practices are seen in the country.

\section{Acknowledgment}

The author would like to thank the British Columbia Institute of Technology Environmental Health department, especially Helen Heacock, for her support and supervision during the research.

\section{Competing Interests}

The authors declare that they have no competing interests. 


\section{References}

1. Athwal, R. (2020). In an Attempt at Saving the Environment, Are You Instead Harming Yourself?. BCIT Environment Health Program.

2. Barbosa, J., Albano, H., Silva, C., \& Teixeira, P. (2019). Microbiological contamination of reusable plastic bags for food transportation. Food Control, 99, 158-163. doi: 10.1016/j.foodcont.2018.12.041

3. BC Centre for Disease Control. (2009). Writing Your Own Food Safety Plan - The HACCP Way [PDF file]. Retrieved from http://www.bccdc.ca/resourcegallery/Documents/Guidelines\%20an $\mathrm{d} \% 20$ Forms/Guidelines\%20and $\% 20$ Manuals/EH/FPS/Food/EnsuringFoo dSafetyHACCPWay.pdf

4. British Columbia Institute of Technology. (2018). Research Ethics for Human Participants [PDF file]. Retrieved from https://www.bcit.ca/files/pdf/policies 16500.pdf

11. Government of Canada. (2019, May 28). Preventing cross-contamination. Retrieved from https://www.inspection.gc.ca/food/re quirements-and-guidance/preventivecontrols-food-businesses/crosscontamination/eng/1511370338415/1 $\underline{528206744716 .}$.

12. Government of Canada. (2012, January 12). Safe food handling practices at the grocery store. Retrieved from https://www.canada.ca/en/healthcanada/services/general-food-safety- tips/safe-food-handling-practicesgrocery-store.html.

13. Government of Manitoba. (n.d.). The Food Safety Connection [PDF file]. Retrieved from https://www.gov.mb.ca/inr/pdf/pubs/ nhfi food safety connection.pdf

17. Klick, J., \& Wright, J. (2012). Grocery Bag Bans and Foodborne Illness. SSRN Electronic Journal. doi: 10.2139/ssrn.2196481

19. Leeuwen, A. v. (2014). Bacterial and Viral Health Hazards of Reusable Shopping Bags. 1-9.

21. Microsoft Office 365. (2019). Microsoft Word for Mac Software.

23. Moreira, F., Christensen, J., Calame, \& Nicholas, A. (2016, April 22). Washing Reusable Bags: How Do I Do It?: Bulletin Bag [.com]. Retrieved from https://www.bulletinbag.com/blog/fa qs/washing-reusable-bags.

27. Silverhill Institute of Environmental Research and Conversation. (2012). The Grocery Bag Controversy.

28. Sinclair, R., Fahnestock, A., Feliz, A., Patel, J., \& Perry, C. (2018). The Spread of a Norovirus Surrogate via Reusable Grocery Bags in a Grocery Supermarket. Advancement of the Science, 7-14.

30. Survey Monkey Canada. Online Surveys in Canada [Internet]. 2019. Available from: https://www.surveymonkey.com/mp/ global/canada/. 
31. Tong, E. (2010). Will going "green" make you green?: Is consumer health at risk due to reusable shopping bags?. Bcit Environmental Health Program.

33. Trudeau, J. (2019, June 10). Canada to ban harmful single-use plastics and hold companies responsible for plastic waste. Retrieved October 18, 2019, from

https://pm.gc.ca/en/news/newsreleases/2019/06/10/canada-banharmful-single-use-plastics-andhold-companies-responsible.

35. Wickett, M. (2019, February 20).

Shuswap plastic bag ban expected to begin July 1. Retrieved October 18, 2019, from

https://www.saobserver.net/news/pla stic-bag-ban-expected-to-begin-july$\underline{1 /}$.

36. Williams, D. L., Gerba, C. P., Maxwell, S., \& Sinclair, R. G. (2011).

Assessment of the Potential for Cross-contamination of Food Products by Reusable Shopping Bags. International Association for Food Protection, 508-513. 